\title{
Evaluasi Kebijakan Pengelolaan Sampah di TPA Kalikondang Kabupaten Demak
}

\section{Evaluation of Waste Management Policies at TPA Kalikondang, Demak Regency}

\author{
Kiki Hardiyanti ${ }^{1}$, Hartuti Purnaweni ${ }^{2}$, Sundarso ${ }^{3}$ \\ Departemen Administrasi Publik Fakultas Ilmu Sosial dan Ilmu Politik Universitas Diponegoro
}

Disetujui: November 2020; Direview: Mei 2021;Diterima: Mei 2021

\begin{abstract}
Abstrak
Tujuan penelitian ini adalah untuk menganalisis kesesuaian kebijakan pengelolaan sampah yamg dilakukan di TPA (Tempat Pembuangan Akhir) Kalikondang Kabupaten Demak. Metode penelitian yang digunakan yaitu penelitian kualitatif deskriptif dengan teknik pengumpulan data diperoleh berdasarkan data primer melalui wawancara langsung, observasi, dan dokumentasi, serta data sekunder melalui jurnal dan studi kepustakaan. Hasil penelitian menunjukkan bahwa efektifitas pengelolaan sampah yang dilakukan masih belum optimal. Berdasarkan Pasal 44 Undang-Undang Nomor 18 Tahun 2008 tentang Pengelolaan Sampah mengamanatkan bahwa paling lambat pada tahun 2013 setiap pemerintah daerah/kota sudah memiliki TPA yang representatif dan memenuhi kaidah teknis maupun lingkungan (sanitary landfill). Namun, TPA Kalikondang masih menggunakan sistem open dumping. Efesiensi pengelolaan sampah belum maksimal, karena penimbunan sampah yang seharusnya dilakukan setiap hari ternyata dilakukan setiap 15 hari sekali, selain itu, kolam air lindi tidak berfungsi secara maksimal. Kecukupan dalam pengelolaan sampah dilihat dari ketepatan kebijakan yang dibuat, namun kebijakan tersebut tidak berjalan sebagaimana mestinya. Responsivitas yang dilakukan dalam menjawab keluhan dari masyarakat terkait pengelolaan sampah yang dilakukan di TPA Kalikondang dinilai tidak menyelesaikan persoalan yang ada, seperti membuat tanggul tanah sebagai pembatas kali TPA dan persawahan warga, yang tentunya tanggul tanah tersebut tetap dapat dilewati oleh air lindi. Ketepatan dalam mengolah tinja menjadi gas metan sudah sesuai, karena pengelolaan tersebut hanya diperuntukkan pegawai di TPA.
\end{abstract}

Kata Kunci: Sampah, Evaluasi Kebijakan, TPA Kalikondang

\begin{abstract}
The purpose of this study was to analyze the suitability of the waste management policy in landfills (TPA) Kalikondang, Demak Regency. The research method used is descriptive qualitative research with data techniques based on primary data, observation, and documentation, as well as secondary data through journals and literature study. The results showed that the effectiveness of waste management was not optimal. Based on Article 44 of Law Number 18 Year 2008 concerning Solid Waste Management, it mandates that by 2013 every regional/city government already has a representative TPA and meets both technical and environmental principles (sanitary landfill), however, TPA Kalikondang still uses the open dumping system. The efficiency of waste management has not been maximized, because the landfill that should have been done every day was actually done once every 15 days, besides that, the leachate pool did not function optimally. Adequacy in waste management is seen from the policies taken, but these policies are not running well. Responsiveness is carried out in handling complaints from the community who manage the waste carried out at the Kalikondang TPA that does not solve existing problems, such as making land embankments as a barrier to the TPA river and residents' rice fields, which of course the land embankment can still be passed by leachate The accuracy in schooling to methane gas is appropriate, because this management is only intended for employees at the TPA
\end{abstract}

Keywords: Garbage, Policy Evaluation, Environmental Service, TPA Kalikondang

How to Cite: Hardiyanti, K., Purnaweni, H \& Sundarso. (2021). Evaluasi Kebijakan Pengelolaan Sampah di TPA Kalikondang Kabupaten Demak. PUBLIKAUMA: Jurnal Ilmu Administrasi Publik UMA, Vol.9 (1): 110

\footnotetext{
*Corresponding author:

E-mail: kikihardiyanti10@gmail.com
}

ISSN 2549-1660 (Print)

ISSN 2580-2011 (Online) 


\section{PENDAHULUAN}

Salah satu peraturan daerah mengenai sampah terdapat pada peraturan yang mengatur tentang permasalahan di Kabupaten Demak, yaitu Peraturan Daerah Kabupaten Daerah Tingkat II Demak No. 17 Tahun 1991 tentang Ketertiban, Kebersihan dan Keindahan dalam Wilayah Kabupaten Daerah Tingkat II Demak. Dalam peraturan tersebut masih sangat sederhana yang hanya mengatur nilainilai normatif seperti larangan membuang sampah sembarangan, menjaga kebersihan dan menyediakan tempat pembuangan sampah. Karena Kabupaten Demak merupakan salah satu kabupaten yang tidak luput mengalami permasalahan sampah.

Kabupaten Demak merupakan salah satu kabupaten yang terletak di Jawa Tengah. Didalam Peraturan Daerah Kabupaten Demak Nomor 8 Tahun 2016 tentang Perlindungan dan Pengelolaan Lingkungan Hidup Kabupaten Demak disebutkan pada Pasal 3 bahwa perlindungan dan pengelolaan lingkungan hidup bertujuan untuk mewujudkan lingkungan hidup daerah yang baik dan sehat. Sasaran pengelolaan lingkungan hidup pada Pasal 4 Ayat (1) point a yaitu terwujudnya Daerah yang Bersih, Elok, Rapi, Anggun, Maju, Aman, dan Lestari (BERAMAL) dalam mewujudkan fungsinya sebagai Kota Beramal yang religius berbasis kebaharian, perdagangan dan jasa.

Undang-Undang Nomor 18 Tahun 2018 tentang sampah terdapat sebuah amanah yang di sampaikan oleh (Mayangkara, 2016) yaitu bahwa sampah menjadi suatu kewajiban bagi pemerintah termasuk pemerintah daerah untuk menjamin terselenggaranya pengelolaan sampah yang baik dan berwawasan lingkungan sebagai upaya peningkatan derajat kualitas lingkungan, kesehatan masyarakat dan menjadikan sampah sebagai sumber daya. Sehingga melalui UU tersebut pemerintah daerah memiliki andil dalam menjawab persoalan sampah didaerahnya.

Dinas Lingkungan Hidup

(DLH)

Kabupaten Demak merupakan suatu badan yang menanggulangi lingkungan hidup, salah satunya yaitu pengelolaan sampah. Kemudian, Kabupaten Demak melalui Peraturan Daerah Kabupaten Demak Nomor 8 Tahun 2016 tentang Perlindungan Dan Pengelolaan Lingkungan Hidup di Kabupaten Demak pada BAB VI tentang Pengendalian Pencemaran Dan
Kerusakan Lingkungan Hidup Pasal 30 Ayat (1) yaitu setiap orang dan penanggung jawab usaha atau kegiatan wajib mencegah pencemaran tanah; Pasal 39 Ayat (1) setiap orang dan/atau penanggung jawab usaha atau kegiatan dilarang melakukan kegiatan yang dapat menimbulkan kerusakan pada keanekaragaman hayati dan ekosistemnya.

Penelitian oleh (Elamin, 2018) mengatakan bahwa terdapat tiga bagian dalam permasalahan sampah menurut Mulasari dalam yaitu bagian hilir, pembuangan sampah selalu meningkat, bagian proses, keterbatasan sumber daya manusia seperti pemerintah maupun masyarakat, dan bagian hulu, sistem yang diterapkan pada pemsrosesan akhir kurang optimal.

TPA Kalikondang dan TPA Candisari menggunakan sistem pengelolaan sampah di kedua TPA tersebut masih menggunakan sistem open dumping. Menurut (Mubarak, 2009) mengatakan Open Dumping sebagai suatu sistem pembuangan sampah yang dilakukan secara terbuka sehingga menimbulkan masalah. Sedangkan (Santoso, 2017) berpendapat bahwa Open dumping merupakan sistem pembuangan paling sederhana karena sampah dibuang kesebuah tempat pembuangan akhir tanpa adanya perlakuan atau pengelolaan lebih lanjut.

Pada lahan penimbunan terbuka, berbagai macam hama dan kuman penyebab penyakit dapat berkembang biak. Gas metana yang dihasilkan oleh pembusukan sampah organik dapat menyebarkan bau busuk melalui udara, selain itu gas metan juga bersifat mudah terbakar. Cairan yang tercampur sampah kemudian dapat merembes ke tanah dan mencemari air tanah, rembesan tersebut dapat membawa zat-zat yang berbahaya bagi kesehatan dan lingkungan. Pada kondisi pengelolaan seperti ini, sebagian besar sampah hanya ditumpuk dalam suatu area TPA yang terbuka. Sehingga pada saat hujan, air rembesan sampah yang dikenal dengan air lindi akan keluar. Apabila tidak dikelola dan diolah dengan baik dan benar, maka akan berpotensi mencemari lingkungan sekitar.

Sistem pengelolaan sampah berdasarkan Pasal 44 Undang-Undang Nomor 18 Tahun 2008 tentang Pengelolaan Sampah mengamanatkan bahwa paling lambat pada tahun 2013 setiap pemerintah daerah/kota sudah memiliki TPA yang representatif dan 
memenuhi kaidah teknis maupun lingkungan (sanitary landfill). Penelitian oleh (Samin, 2017) mengatakan bahwa Sanitary landfill merupakan pengembangan atau tingkatan dari pengelolaan sampah secara open dumping karena dinilai sudah tidak layak digunakan pada tempat pembuangan akhir sampah. Namun, pada kenyataannya operasional TPA di Indonesia sebagian besar masih berupa sistem open dumping, termasuk Kabupaten Demak.

Berdasarkan pada uraian permasalahan diatas, maka penelitian ini akan mengkaji dan mengevaluasi terkait dengan bagaimana kesesuaian sistem kebijakan pengelolaan sampah khususnya di TPA Kalikondang Kabupaten Demak.

\section{METODE PENELITIAN}

Penelitian ini dilakukan di TPA Kalikondang Kabupaten Demak yang membahas mengenai pengelolaan sampah. Unit analisis yang digunakan adalah segala bentuk pengelolaan sampah yang dilakukan di TPA Kalikondang karena sistem yang digunakan masih open dumping.

Penelitian ini menggunakan pendekatan kualitatif yang bersifat deskriptif dengan fokus penelitian untuk mengetahui pengelolaan sampah yang dilakukan. Penelitian dilakukan dengan melakukan wawancara yang dikelompokkan menjadi tiga informan dipilih menggunaan teknik purposive sampling, dengan kriteria 1) Kepala Seksi pengelolaan Sampah DLH Kabupaten Demak, 2) Koordinator TPA Kalokondang, 3) Masyarakat sekitar TPA Kalikondang.

Pengumpulan data dilakukan dengan wawancara mendalam, dokumentasi, obsevasi lapangan dan studi kepustakaan. Kemudian data di analisis menggunakan model evaluasi kebijakan menurut (Dunn, 2003) yaitu efektivitas, efesiensi, kecukupan, perataan, responsivitas, dan ketepatan. Keabsahan data diperoleh berdasarkan triangulasi waktu dan sumber.

\section{HASIL DAN PEMBAHASAN Pengelolaan Sampah}

Pemerintah daerah memiliki tanggungjawab terhadap pengelolaan sampah. Aspek persampahan yang terdapat di dalam Undang-undang Nomor 23 Tahun 2014 tentang Pemerintahan Daerah Pasal 11 Ayat
(2) yaitu urusan pemerintah wajib sebagaimana dimaksud pada Ayat (1) terdiri atas urusan pemerintah yang berkaitan dengan pelayanan dasar dan urusan pemerintah yang tidak berkaitan dengan pelayanan dasar. Kemudian, Pasal 12 Ayat (1) tentang Urusan Pemerintahan Wajib yang berkaitan dengan pelayanan dasar poin (c) yaitu pekerjaan umum dan penataan ruang, dan Ayat (2) tentang Urusan Pemerintah Wajib yang tidak berkaitan dengan pelayanan dasar poin (e) yaitu lingkungan hidup.

Dinas Lingkungan Hidup Kabupaten Demak memiliki kewajiban untuk turut serta dalam mewujudkan Visi Pembangunan Kabupaten Demak tahun 2016-2021, sebagaimana yang telah di tetapkan dan tercantum dalam Rencana Pembangunan Jangka Menengah Daerah Kabupaten Demak Tahun 2016-2021 yaitu "Terwujudnya Masyarakat Demak yang Agamis Lebih Sejahtera, Mandiri, Maju, Kompetitif, Kondusif, Berkepribadin dan Demokratis". Dinas Lingkungan Hidup Kabupaten Demak untuk menjawab amanat diatas dengan mempertimbangkan tugas, fungsi dan kedudukannya menetapkan visi 2016-2021 sebagaimana yang telah di tetapkan dan tercantum dalam Rencana Strategis Dinas Lingkungan Hidup Kabupaten Demak Tahun 2016-2021 Pada Bab IV Tentang Tujuan dan Sasaran, Strategi dan Kebijakan yaitu "Terwujudnya Pengembangan Potensi Kabupaten Demak dalam Pembangunan Berkelanjutan yang Berwawasan Lingkungan Menuju Kemandirian Daerah".

Sistem pengelolaan sampah yang terdapat di TPA Kalikondang masih open dumping, seperti yang disampaikaninforman melalui wawancara berikut:

"Walaupun sudah ada pengelolaan tetapi TPA Kaikondang masih menggunakan sistem open dumping". (Wawancara, 8 Januari 2019)

Pengelolaan sampah di Kabupaten Demak khususnya TPA masih belum mencapai target seperti yang terdapat pada Pasal 44 Undang-Undang Nomor 18 Tahun 2008 tentang Pengelolaan Sampah mengamanatkan bahwa paling lambat pada tahun 2013 setiap pemerintah daerah/kota sudah memiliki TPA yang representatif dan memenuhi kaidah teknis maupun lingkungan (sanitary landfll) 
karena TPA Kalikondang masih menggunakan sistem open dumping.

\section{Evaluasi Kebijakan}

Menurut (Dunn, 1988) menjelaskan bahwa evaluasi kebijakan merupakan tahap kelima. Pada tahap tersebut kebijakan yang telah dijalankan akan dinilai dan dievaluasi, sehingga bisa mengetahui sejauh mana kebijakan yang ditetapkan mampu memecahkan masalah yang dihadapi oleh masyarakat. Selain itu, evaluasi kebijakan dinyatakan sebagai usaha untuk menilai konsekuensi dari kebijakan yang telah ditetapkan berdasarkan pada kriteria dan standar yang dibuat (Lester dan Stewart, 2000). Sehingga, dengan melakukan evaluasi kebijakan dapat diketahui sejauh mana capaian kebijakan yang telah dilaksanakan tersebut.

Selanjutnya (Dunn, 2003) mengatakan bahwa terdapat kriteria dalam melakukan evaluasi kebijakan, yaitu sebagai berikut:

\section{1) Efektivitas}

Efektivitas, dengan melihat sejauh mana capaian kebijakan yang telah dilaksakan, selain itu melihat keterkaitan antara hasil yang diharapkan dengan hasil yang sesungguhnya dicapai.

Temuan penelitian oleh (Hendra, 2016) menjelaskan Sanitary Landfill menjelaskan sebagai sistem pemusnahan sampah yang paling baik, dimana sampah ditimbun dengan tanah selapis demi selapis, sehingga sampah tidak berada diruang terbuka dan dapat meminimalisir dampak yang ditimbulkan. Sehingga, sanitary landfill merupakan suatu metode yang memperhatikan aspek sanitasi lingkungan, namun walaupun begitu sampah yang menumpuk di TPA menghasilkan air lindi yang jika tidak terdapat pengelolaan air lindi akan mencemari air tanah disekitarnya. Semakin banyak tumpukan sampah, maka air lindi yang dihasilkan semakin banyak. Namun, TPA Kalikondang masih menggunakan sistem open dumping yang dapat dilihat pada gambar berikut:

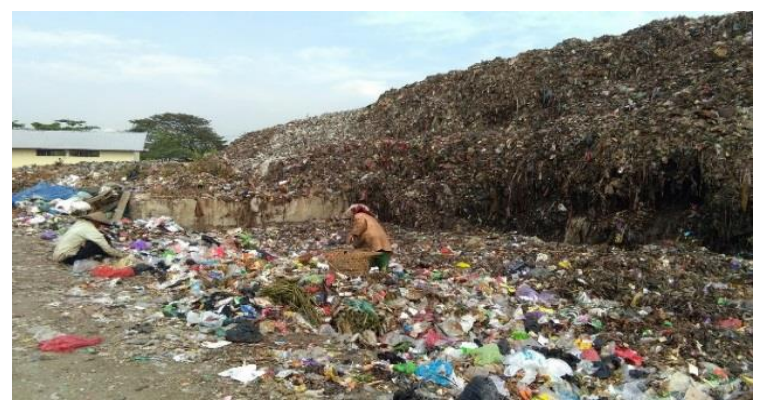

Gambar 1. Tumpukan Sampah

Sumber: Data Olahan Peneliti

Berdasarkan Gambar 1, maka dapat dilihat bahwa sistem yang terdapat pada TPA Kalikondang menggunakan sistem open dumping. Hal tersebut sejalan dengan pendapat Kepala Seksi Pengelolaan Sampah DLH Kabupaten Demak yang mengatakan:

"Tetapi TPA kita itu masih open dumping". (Wawancara, 8 Januari 2019)

Berdasarkan uraian di atas, dapat dilihat bahwa TPA Kalikondang menggunakan sistem Open Dumping yang dijelaskan oleh (Mubarak ,2009) sebagai suatu sistem pembuangan sampah yang dilakukan secara terbuka sehingga menimbulkan masalah. Kemudian, (Sari, 2017) mengatakan bahwa dengan sistem open dumping, maka pada lahan penimbunan terbuka, berbagai macam hama dan kuman penyebab penyakit dapat berkembang biak. Gas metana yang dihasilkan oleh pembusukan sampah organik dapat menyebarkan bau busuk melalui udara, selain itu gas metan juga bersifat mudah terbakar. Cairan yang tercampur sampah kemudian dapat merembes ke tanah dan mencemari air tanah, rembesan tersebut dapat membawa zat-zat yang berbahaya bagi kesehatan dan lingkungan.

Cairan yang dimaksud di atas adalah air lindi. Menurut (Hartini, 2018) menjelaskan air lindi mengandung bakteri patogen, bahanbahan kimia organik dan anorganik yang berpotensi menyebabkan pencemaran air tanah, lingkungan dan manusia. 


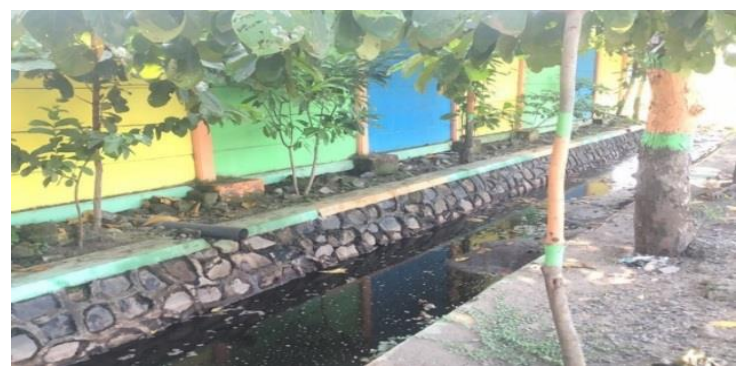

Gambar 2. Saluran Pembuangan Air Lindi Sumber: Data Olahan Peneliti

Berdasarkan Gambar 2, memperlihatkan genangan air lindi pada sebuah kali yang terletak di depan TPA Kalikondang. Kali tersebut merupakan salah satu pengairan area persawahan masyarakat disekitarnya.

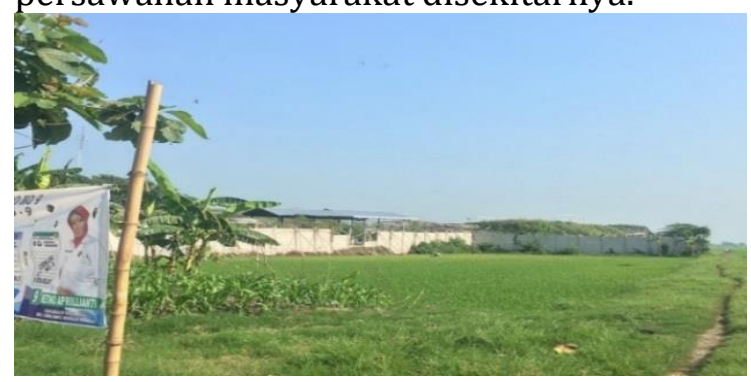

Gambar 3. Lokasi TPA Kalikondang Sumber: Data Olahan Peneliti

Gambar 3, menunjukkan bahwa TPA Kalikondang berbatasan langsung dengan area persawahan masyarakat, sehingga terdapat indikasi adanya pencemaran air di kali yang kemudian berdampak pada hasil pertanian masyarakat (Arbi, 2018).

Berdasarkan uraian di atas, maka dapat dilihat bahwa capaian pengelolaan TPA tidak tercapai, karena sistem pengelolaan yang masih menggunakan sistem open dumping, sedangkan seharusnya sejak tahun 2013 sudah menggunakan sistem sanitary landfill dan tercemarnya tanah dan air disebabkan air lindi.

\section{2) Efesiensi}

Upaya perbaikan pengelolaan sampah di Kabupaten Demak sudah dilakukan. Namun, program atau kegiatan yang telah ditetapkan oleh suatu organisasi terkadang terdapat beberapa kendala yang terjadi dalam pencapaian tujuan. Hal tersebut seperti yang disampaikan Kepala Seksi Pengelolaan Sampah DLH Kabupaten Demak sebagai berikut:

"TPA kita ada keterbatasan tempat pembuatan pupuk kompos, mesin pencacah sampah hanya ada dua sehingga sampah yang sudah di cacah tersebut hanya ditumpuk, sedangkan sampah yang masuk itu banyak, gimana mau melakukan pengelolaan setiap hari. Kita juga mengupayakan untuk dapat menutup sampah dengan tanah setiap harinya, namun tidak kesampaian hanya bisa 15 hari sekali karena bego cuma dua. Pupuk juga tidak mesti sebulan sekali mbak, karena tempat yang kecil dan pupuk kompos kita pack itu sekitaran sebulan atau tergantung pengelolaan yang dilakukan mbak bisa sebulan atau lebih, terus yang sudah kita pack begitu masih banyak menumpuk karena yang beli hanya masyarakat, itupun kalau-kalau ada yang beli". (Wawancara, 8 Januari 2019)

Dari uraian di atas dapat diketahui bahwa khususnya di TPA Kalikondang sudah terdapat pengelolaan sampah walaupun sistemnya masih tergolong open dumping. Bego di TPA Kalikondang berjumlah dua buah, dan DLH sudah mengupayakan untuk menutup setiap hari namun terkendala karena hanya memiliki dua Bego dengan TPA yang luas, sehingga pengurukan dan penutupan sampah dengan tanah oleh Bego dilakukan setiap 15 hari sekali. Pemilahan sampah dilakukan menggunakan dua mesin pencacah sampah, namun dua mesin pencacah tersebut tidak bisa untuk mengolah sampah yang masuk setiap harinya. Sampah yang masuk di angkut oleh truk sampah, kemudian beberapa sampahnya di taruh di tempat pencacahan sampah, kemudian pemilahan dilakukan. Setelah pemilahan dilakukan, maka dihasilkanlah sampah organik dan non-organik, yang dapat dilihat sebagai berikut:

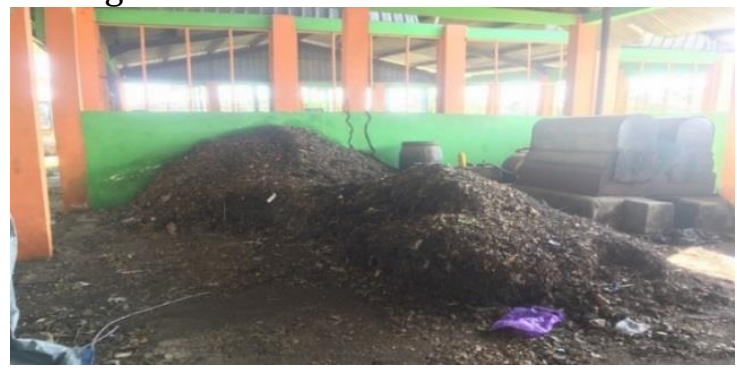

Gambar 4. Tumpukan Sampah Organik Sumber: Data Olahan Peneliti

Sampah organik kemudian dibuat menjadi pupuk kompos. Namun, tempat untuk membuat pupuk kompos tidak memadai dalam 
artian dengan ukuran yang kecil, sehingga pembuatan pupuk kompos berpengaruh terhadap waktu dan jumlah sampah yang di cacah. Tempat penyimpanan pupuk kompos dapat dilihat pada gambar berikut:

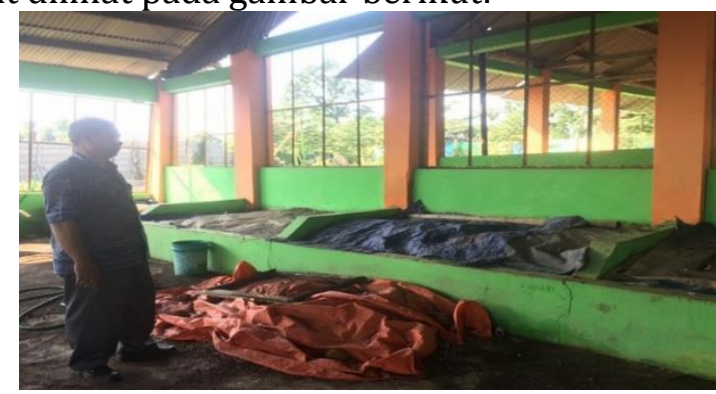

Gambar 5. Tempat Penyimpanan Pupuk Kompos Sumber: Data Olahan Peneliti

TPA Kalikondang memiliki kolam air lindi yang belum digunakan dengan optimal, karena kolam air lindi tidak di operasikan sebagai mana diperuntukkan. Selain itu, masih terdapat air lindi yang menggenang di disekitaran TPA tanpa melalui pengelolaan agar air lindi menjadi stabil dan aman terhadap lingkungan (Said, 2018).

TPA Kalikondang juga memiliki kolam tinja berupa bak terbuka yang berisi buangan tinja dari truk yang menyedot septitank rumah warga. Kolam tinja tersebut dipergunakan sebagai gas metana yang lingkup penggunaanya masih digunakan oleh orangorang TPA atau kantor di TPA Kalikondang.

\section{3) Kecukupan}

Menurut (Dunn, 2003) mendefinisikan kecukupan berkaitan dengan seberapa jauh suatu tingkat efektivitas memuaskan nilai, kebutuhan, kesempatan dalam menumbuhkan masalah. Mengenai kecukupan ini disampaikan koordinator TPA Kalikondang Kabupaten Demak sebagai berikut:

"Kita kekurangan tempat pembuatan pupuk kompos, mesin kurang mbak, personil juga kurang karena ya kadang tim bersih-bersih yang nyapu tetep kotor mbak tidak terjangkau seluruhnya. Sebenarnya kalau permasalahan yang paling sering terjadi itu keluhan akan bau dan air lindi dari masyarakat, karena air lindi kita pemprosesannya masih baru sampai tahap kincir dan itu juga masih baru bulan kemarin dan sekarang lagi rusak dan belum ada perbaikan. Air lindi ini walaupun sudah di tampung kan air yang ditampung di kolam harus dikeluarkan karena akan penuh. Air lindi bersifat mencemari lingkungan karena belum ada proses pengelolaannya nya, apalagi saluran pembuangannya itu mengenai persawahan warga disebelah". (Wawancara, 8 Januari 2019)

Berdasarkan uraian di atas, maka dapat diketahui bahwa penutupan timbunan sampah dengan tanah seharusnya dilakukan setiap hari, namun penimbunan tanah dilakukan 15 hari sekali. Selain karena kurangnya Bego, terdapat keterbatasan alat dan pekerja Bego karena jika salah satu tidak bisa hadir maka akan menghambat proses penimbunan. Pencacahan sampah tidak dilakukan setiap hari karena tempat penyimpanan sampah yang sudah dipilah dan tempat pembuatan pupuk kompos tidak memadai. Selain itu, sampah organik yang sudah menjadi pupuk kompos tidak ada pendistribusian penjualan, sehingga pupuk hanya dijual jika ada masyarakat yang langsung membeli ke TPA atau adanya pemesanan pupuk. Kurun waktu pembuatan pupuk juga disesuaikan berdasarkan tersedianya tempat untuk mengendapkan pupuk kompos dalam kotak-kotak atau tempat pupuk kompos sebelum kemudian di pack seperti gambar berikut:

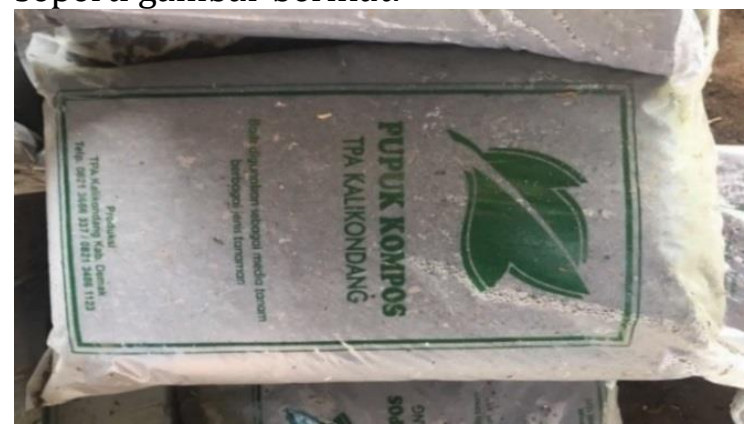

Gambar 6. Pupuk Kompos TPA Kalikondang Sumber: Data Olahan Peneliti

Mengenai bau tersebut, warga sekitar mengatakan:

"Karena tumpukan sampah di TPA terbuka, jadi ya bau terus apalagi sewaktu musim hujan ". (Wawancara, 8 Januari 2019)

Selain itu, warga juga mengatakan:

"TPA Kalikondang berlokasi sangat dekat dengan permukiman warga, sekitar 100 $m$. Hal tersebut tentu saja sangat mengganggu terutama bau sampah, apalagi jika sedang saat musim hujan". 
Dari uraian di atas, maka dapat dilihat bahwa bau sampah sangat mengganggu masyarakat sekitar karena penumpukan sampah di TPA Kalikondang terbuka. Oleh (Darnas, 2016) menyebutkan bahwa jarak minimal TPA Sampah ke permukiman adalah lebih dari 500 m. Namun, TPA Kalikondang berjarak sekitar $100 \mathrm{~m}$ dari permukiman masyarakat.

\section{4) Perataan}

Perataan mengenai keadilan yang diberikan oleh pemangku kebijakan kepada sasaran kebijakan. Hal tersebut seperti yang disampaikan Kepala Seksi Pengelolaan Sampah DLH Kabupaten Demak sebagai berikut:

"Seksi Pengelolaan Sampah Kabupaten Demak ini hanya berfokus dalam penanganan atau pengelolaan sampah saja mbak, dan mengenai anggaran pertahunnya digunakan untuk membeli BBM dan tanah yang digunakan untuk menimbun sampah, dan dana ini sudah cukup". (Wawancara, 8 Januari 2019)

Pengelolaan sampah yang dilakukan ternyata pembiayaannya belum menyeluruh merata, dalam artian hanya berfokus pada pembelian tanah dan BBM truk pengangkutan sampah. Padahal perlu juga adanya biaya untuk memperbaiki alat yang rusak, misalnya pada kolam kedua air lindi terdapat kincir atau turbin yang beguna untuk memutar dan menambah kadar oksigen dalam air lindi (Mumtahanah, 2017).

Kincir pada kolam kedua air lindi di TPA Kalikondang dan sedang dalam keadaan rusak, dapat dilihat sebagai berikut:

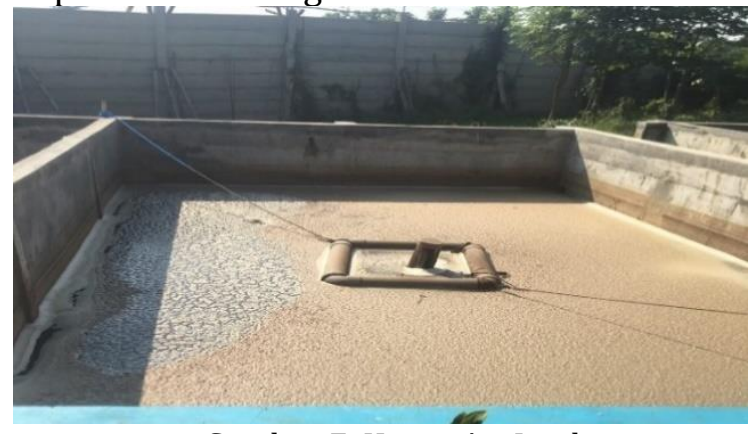

Gambar 7. Kincir Air Lindi

Sumber: Data Olahan Peneliti

Gambar 7, menunjukkan bahwa air lindi tergenang dan kincir dalam keadaan mati dikarenakan dalam keadaan rusak. Oksigen yang cukup sangat penting untuk membantu mikroorganisme fakultif aktif maupun aerobik dalam mendegradasi biodegradable yang terdapat dalam lindi sebagai bahan pencemar Nurhasnah (2011) mengatakan semakin kencang laju aerasi atau kincir berputar, maka oksigen yang masuk kedalam air lindi semakin tinggi.

Selanjutanya dijelaskan oleh Nurhasnah (2011) bahwa pemberian udara (oksigen) pada laju yang semakin besar akan meningkatkan $\mathrm{pH}$ yang semakin tinggi berkaitan dengan perubahan senyawa bersifat asam menjadi senyawa bersifat lebih basa.

\section{5) Responsivitas}

Menurut (Dunn, 2003) mengatakan bahwa responsivitas berkaitan dengan seberapa jauh dapat memuaskan sasaran kebijakan dari kebijakan yang diterapkan.

Air lindi yang berada disekitaran TPA tentunya memberikan dampak terhadap lingkungan sekitar. Genangan air lindi yang berada tepat di kali depan TPA Kalikondang langsung berbatasan dengan pertanian masyarakat. Terdapat pengaduan dari masyarakat, seperti yang disampaikan oleh Koordinator TPA Kalikondang sebagai berikut:

"Masyarakat khususnya sekitar TPA ini mengeluh bau sampah sama air lindi mengenai persawahan masyarakat, karena memang kita masih menggunakan sistem open dumping". (Wawancara, 8 Januari 2019)

Kemudian melanjutkan sebagai berikut:

"Air lindi bersifat mencemari lingkungan karena belum ada proses pengelolaannya, apalagi saluran pembuangannya itu mengenai persawahan warga disebelah". (Wawancara, 8 Januari 2019)

Dari uraian di atas, terdapat keluhan yang dirasakan oleh masyarakat. Keluhan tersebut terkait bau dan air lindi yang mengenai persawahan masyarakat. Keluhan tersebut langsung ditanggapi oleh pihak TPA Kalikondang, seperti yang disampaikan Koordinator TPA Kalikondang berikut:

"Setiap ada permasalahan kita langsung sampaikan ke pimpinan, dan langsung menemui yang bersangkutan. Diobrolkan langsung dan kemudian dicari jalan 
terbaik dengan di bendung begitu mbak". (Wawancara, 8 Januari 2019)

Solusi yang diberikan yaitu dengan membendung air lindi tersebut dengan membangun tanggul agar air lindi tersebut tidak mengenai persawahan warga di sebelah TPA Kalikondang. Namun, tanggul tersebut ternyata berupa tanggul tanah yang kemudian menutup kali tepat pada perbatasan antara TPA dan lahan pertanian masyarakat. Walaupun begitu, air lindi menggenang dan tetap dapat meresap dalam tanah, seperti yang disampaikan warga sekitar:

"Tanggul tanah tentu dapat merembes dan dilewati oleh air, jadi ya tetap saja tercemar". (Wawancara, 8 Januari 2019) Dapat dilihat pada gambar berikut:

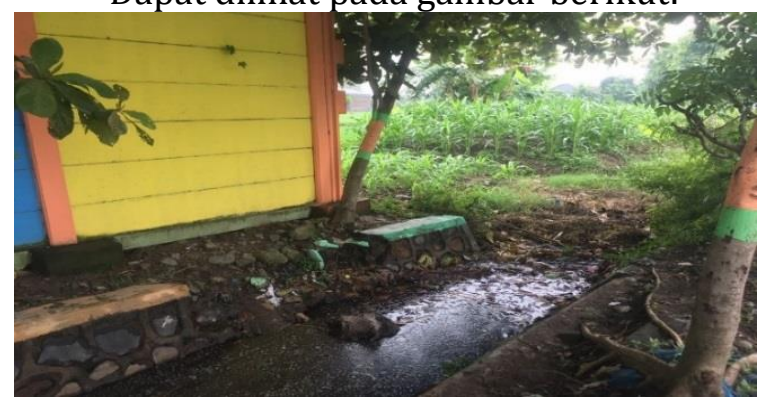

Gambar 8. Tanggul Air Lindi di Dekat Persawahan Masyarakat

Sumber: Data Olahan Peneliti

Berdasarkan uraian di atas, solusi terhadap pencemaran air lindi dilakuakan dengan membuat tanggul tanah, namun Arbi (2018) menjelaskan bahwa pencemaran air tanah yang disebabkan oleh air lindi dapat merembes dan mengalir mengikuti aliran air tanah.

Peraturan Menteri Pekerjaan Umum Republik Indonesia Nomor 03/PRT/M/2013 tentang Penyelenggaraan Prasarana Dan Sarana Persampahan dalam Penangan Sampah Rumah Tangga dan Sampah Sejenis Sampah Rumah Tangga Pasal 35 Ayat (2) poin E disebutkan bahwa jarak dari TPA ke permukiman adalah lebih dari $1 \mathrm{Km}$ dengan mempertimbangkan pencemaran lindi, kebauan, penyebaran vektor penyakit, dan aspek sosial. Namun, jarak TPA Kalikondang ke permukiman kurang lebih berjarak $100 \mathrm{~m}$, sehingga menimbulkan keluhan bau sampah.

Penentuan lokasi TPA harus mempertimbangkan berbagai hal seperti berdasarkan Keputusan Dirjen Pemberantasan Penyakit Menular dan Penyehatan Pemukiman
Departemen Kesehatan Nomor 281 Tahun 1989 tentang Persyaratan Kesehatan Pengelolaan Sampah, sebagai berikut:

Pengelolaan sampah yang baik dan memenuhi syarat kesehatan merupakan salah satu upaya untuk mencapai derajat kesehatan yang mendasar. Masyarakat perlu dilindungi dari kemungkinan gangguan kesehatan akibat pengelolaan sampah sejak awal hingga tempat pembuangan akhir.

\section{6) Ketepatan}

Di TPA Kalikondang terdapat kompor yang gasnya berasal dari kolam tinja yaitu biogas metan, seperti yang disampaikan Koordinator TPA Kalikondang sebagai berikut:

"Pupuk kompos, minyak atau bio solar dan emisi gas metana. Namun, bio solar yang sudah diproses tidak ada kegiatan lanjutan dan gas metana digunakan oleh pegawai di TPA Kalikondang jika dibutuhkan untuk memasak seperti itu mbak". (Wawancara, 8 Januari 2019)

\section{Pengelolaan tinja menjadi biogas} menurut Mulyani (2015) merupakan salah satu cara untuk mengurangi pemanasan global secara signifikan. Manfaat lainnya disebutkan oleh Romadhona (2020) seperti dapat mengurangi emisi gas rumah kaca, pencemaran udara, serta pemanasan global. Sehingga diharapkan dapat mengurangi ketergantungan masyarakat atau alternatif lain dari penggunaan minyak karena minyak memiliki jumlah terbatas dan merupakan sumberdaya tidak terbarukan.

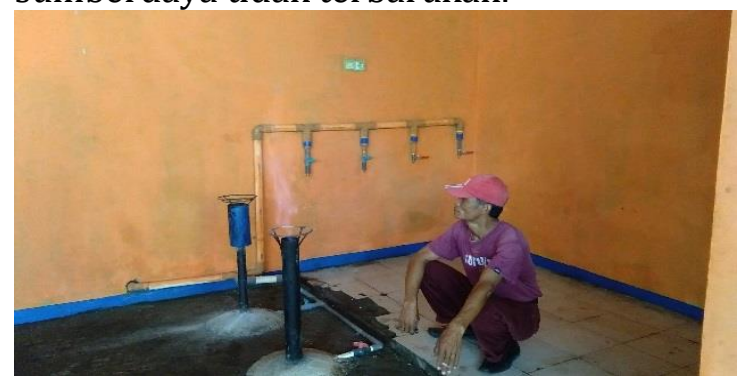

Gambar 9. Kompor Gas Metan

Sumber: Data Olahan Peneliti

Gambar 9, menunjukkan salah satu pekerja di TPA Kalikondang yang menghidupkan kompor gas mentan yang biasa digunakan seperti untuk memasak. 


\section{SIMPULAN}

Berdasarkan analisis yang sudah dilakukan, maka penelitian mengenai evaluasi kebijakan pengelolaan sampah di Kabupaten Demak belum maksimal. Hal tersebut dapat dilihat dari kriteria yang digunakan, seperti efektivitas yang masih belum optimal dikarenakan sistem pengelolaan sampah masih menggunakan sistem open dumping. Efesiensi yang masih belum optimalnya pengelolaan sampah yang terdapat di TPA Kalikondang seperti penimbunan sampah dengan tanah, pencacahan sampah, pembuatan pupuk kompos, kolam tinja dan kolam air lindi dikarenakan kurangnya sarana dan prasarana yang tersedia. Selain itu, biaya pengelolaan sampah terfokus hanya pada pembelian tanah dan BBM truk pengangkut sampah.

Belum maksimalnya pengelolaan sampah di Kabupaten Demak juga dapat dilihat melalui kriteria Kecukupan yang masih belum optimal dikarenakan pengelolaan sampah yang dilakukan tidak berjalan sesuai dengan jadwal seharusnya. Perataan yang masih belum optimal dikarenakan pembiayaan masih berfokus pada pembelian BBM untuk truk pengangkutan sampah dan pembelian tanah. Responsivitas yang masih belum optimal dikarenakan masih terdapat pengaduan dari masyarakat seperti bau dan air lindi, serta solusi yang diberikan dari Dinas Lingkungan Hidup Kabupaten Demak tidak menyelesaikan persoalan yang terjadi. Kemudian Ketepatan masih belum optimal karena penggunaan gas metan hanya sebatas keperluan pekerja di TPA Kalikondang.

\section{DAFTAR PUSTAKA}

Arbi, Yaumal. 2018. Kajian Pencemaran Air Tanah oleh Lindi di Sekitar Tempat Pembuangan Akhir Sampah Air Dingin Kota Padang. Jurnal Sains dan Teknologi, 18(1): 2.

Darnas, Yeggi. 2016. Studi Kelayakan Lokasi Tempat Pemrosesan Akhir (TPA) Sampah Kabupaten Padang Pariaman. Seminar Nasional Sains dan Teknologi Lingkungan II, e-ISSN 2541-3880.

Dunn, William N. (1988). Analisa Kebijaksanaan Publik. Yogyakarta: Hanindita Press.

Dunn, William N. (2003). Pengantar Analisis Kebijakan Publik (edisi kedua), Yogyakarta: Gadjah Mada University Press.

Elamin, Muchammad Zamzami, dkk. (2018). Analisis Pengelolaan Sampah Pada Masyarakat Desa Disanah Kecamatan Sreseh
Kabupaten Sampang. Jurnal Kesehatan Lingkungan, 10(4): 369.

Hartini, Elya dan Yanto Yulianto. [2018]. Kajian Dampak Pencemaran Lindi Tempat Pemrosesan Akhir (TPA) Ciangir Terhadap Kualitas Air dan Udara. Jurnal Siliwangi, 4(1): 28.

Hendra, Yulia. (2016). Perbandingan Sistem Pengelolaan Sampah Di Indonesia Dan Korea Selatan: Kajian 5 Aspek Pengelolaan Sampah. Jurnal Aspirasi, 7(1): 81.

Keputusan Dirjen Pemberantasan Penyakit Menular dan Penyehatan Pemukiman Departemen Kesehatan Nomor 281 Tahun 1989 tentang Persyaratan Kesehatan Pengelolaan Sampah.

Lester, James P. \& Stewart Jr., Joseph. (2000). Public Policy: An Evolutionary Approach. Belmont: Wadsworth.

Mayangkara, Agung Prasetya., dkk. (2016). Evaluasi Kebijakan Pengelolaan Sampah Di Tpa Gunung Panggung Kabupaten Tuban. Jurnal Penelitian Administrasi Publik, 2(2): 428.

Mubarak, Wahid Iqbal \& Nurul C. (2009). Ilmu Kesehatan Masyarakat Teori dan Aplikasi. Jakarta: Salemba Medika.

Mumtahanah, Mahda dkk. 2017. Pengolahan Limbah Lindi TPA Kota Madiun Melalui Kombinasi Metode Filtrasi dan Fitoremediasi Sistem Lahan Basah Buatan Menggunakan Tumbuhan Bambu Air. Prosiding SNST Ke-8 Tahun 2017.

Muthmainnah, dan Adris. 2020. Pengelolaan Sampah di Tempat Pembuangan Akhir (TPA) Patommo Sidrap (Tinjauan Yuridis Peraturan Daerah No. 7 Tahun 2016 Tentang Pengelolaan Persampahan). Madani Legal Review, 4(1):32.

Mulyani, Tri., dkk. (2011). EcoDevelopment Menuju MDGs 2015. Jurnal Ilmiah Mahasiswi, 1(1): 16.

Nurhasanah, \& Latifah K. Darusman. (2011). Efektivitas Pemberian Udara Berkecepatan Tinggi Dalam Menurunkan Polutan Leachate TPA Sampah : Studi Kasus Di TPA Sampah Galuga Kota Bogor. Forum Pascasarjana, 34(1): 68.

Peraturan Daerah Kabupaten Demak Nomor 8 Tahun 2016 tentang Perlindungan dan Pengelolaan Lingkungan Hidup Kabupaten Demak.

Peraturan Daerah Kabupaten Demak Nomor 8 Tahun 2016 tentang Perlindungan Dan Pengelolaan Lingkungan Hidup di Kabupaten Demak pada BAB VI tentang Pengendalian Pencemaran Dan Kerusakan Lingkungan Hidup Pasal 30 Ayat (1) dan Pasal 39 Ayat (1). 
Kiki Hardiyanti, Evaluasi Kebijakan Pengelolaan Sampah di TPA Kalikondang Kabupaten Demak

Peraturan Daerah Kabupaten Daerah Tingkat II Demak No. 17 Tahun 1991 tentang Ketertiban, Kebersihan dan Keindahan dalam Wilayah Kabupaten Daerah Tingkat II Demak.

Peraturan Menteri Pekerjaan Umum Republik Indonesia Nomor 03/PRT/M/2013 tentang Penyelenggaraan Prasarana Dan Sarana Persampahan.

Romadhona, dkk. (2020). Pemanfaatan Biogas Sebagai Sumber Alternatif Tenaga Listrik Di BBPTU HTP Baturraden. Jurnal Techno, 21(1): 22.

Rencana Strategis Dinas Lingkungan Hidup Kabupaten Demak Tahun 2016-2021 Pada Bab IV Tentang Tujuan dan Sasaran, Strategi dan Kebijakan Said, Nusa Idaman. 2015. Pengelolaan Air Lindi Dengan Proses Biofilter Anaerob-Aerob dan Denitrifikasi. JAI, 8(1):5.

Samin, dkk. (2017). Perencanaan Tempat Pemrosesan Akhir Sampah dengan Menggunakan Metode Sanitary Landfill (Studi Kasus: TPA Randuagung Kabupaten Malang). ISSN 1693-3095, 1(2):119.

Santoso, Astya Jayanti Kurnia., dkk. (2016). Tempat Pembuangan Akhir (TPA) Kaliori Sebagai Wisata Edukasi Di Kabupaten Banyumas Dengan Penekanan Desain Pada Pengelolaan Sekuen Ruang. Arsitektura, 14(2):1.

Sari, Resti Nanda dan Afdal. 2017. Karakteristik Air Lindi (Leachate) di Tempat Pembuangan Akhir Sampah Air Dingin Kota Padang. Jurnal Fisika, 6(1): 93.

Undang-Undang Nomor 18 Tahun 2008 Pasal 44 tentang Sistem Pengelolaan Sampah.

Undang-undang Nomor 23 Tahun 2014 tentang Pemerintahan Daerah Pasal 11 Ayat (1), Ayat (2), dan Pasal 12 Ayat (1), Ayat (2). 